\title{
Barriers to implement energy efficiency investment measures in Swedish co-operative apartment buildings
}

\author{
Gireesh Nair $^{1 *}$, Leif Gustavsson ${ }^{1,2}$, Krushna Mahapatra ${ }^{1}$ \\ ${ }^{1}$ Mid Sweden University, Östersund, Sweden \\ ${ }^{2}$ Linnaeus University, Växjö, Sweden \\ *Corresponding author. Tel: +46 63165428, Fax: +46 63165500, E-mail: gireesh.nair@miun.se
}

\begin{abstract}
We sent a questionnaire to chairmen of 3000 co-operative hosing association across Sweden to analyse their perception about energy efficiency aspects during June-October 2010, and 24\% responded. About $80-95 \%$ of the respondents had no intention to retrofit their building envelope components during the next ten years measures. A greater proportion of respondents perceived that energy efficient windows were more advantageous than improved attic, basement and external wall insulation. Respondents gave high priority to economic factors in deciding on an energy efficiency investment measure. For 54\% of the respondents, lack of expertise of the executive board to assess the benefits of energy efficiency measures was a barrier to energy efficiency investments. Majority of respondents considered economic policy instruments, like investment subsidies and tax deductions, as the most effective method to improve energy efficiency.
\end{abstract}

Keywords: Co-operative apartment buildings, energy efficiency, Sweden

\section{Introduction}

In Sweden, the residential and service sector's final energy use in 2008 was about $141 \mathrm{TWh}$, or $36 \%$ of the national final energy use [1]. Building envelope components offer a large potential to reduce energy use in existing buildings as they are important source of heat loss. For example, approximately 15 TWh of heat is lost annually through windows of Swedish residential buildings [2], and this loss could be reduced significantly by upgrading the window stock [3]. Sweden has around 2.44 million dwellings in multi-storey buildings [4], which constitute about $55 \%$ of the total dwelling units. These buildings provide considerable opportunities for energy efficiency measures and many of them were built in the million house programme ${ }^{1}$, and require renovation.

The ownership pattern of multi-storey apartment buildings can be categorised into municipal, private and tenant-ownership (henceforth co-operative). Approximately $40 \%$ of apartments in multi-storey buildings belong to municipal housing companies, while the rest is equally shared by private companies and co-operative housing associations. The municipal housing and private companies give their apartments for rent, while the co-operative sector resembles a condominium sector [5]. In this paper we discuss co-operative housing associations plan to replace/change their building envelope components, and the barriers to implement investment intensive energy efficiency measures.

There are about 26500 co-operative housing associations in Sweden. These housing associations usually do not have individual measurements for heating and hot water consumption. Typically, the billing for heating and hot water use is included in a monthly rent and is based on the apartment size. The household electricity bill is usually metered separately, and charged to individual apartment owners. The decisions pertaining to the buildings are usually made by the executive board which is headed by a chairman. The executive board members and the chairman are elected by the members of the association and

\footnotetext{
${ }^{1}$ The decision to built one million dwelling was made in 1965 to address the housing shortage and to stimulate the construction industry.
} 
they occupy the post for a specific time period. The chairmen are in a good position to share information about the implementation of energy efficiency measures in their association's buildings. The paper is based on the response of the chairmen of co-operative housing associations to our questionnaire.

\section{Theoretical Background}

Potential adopters consider adopting an innovation if they feel a need for it [6]. Need is a state of dissatisfaction or frustration that occurs when there is a difference between the desire and perceived actual state [7], i.e., when a problem is recognised [8]. Potential adopters may gather information on various alternatives and process the information to make the decision that best fulfil their prioritised need [8]. In doing so, they usually compare various alternatives based on their perception of the alternatives' attributes, e.g. investment cost, environmental performance, ease of installation. A measure that has greater perceived advantages compared to others is likely to be adopted.

In building envelope component replacement decisions, need may arise because of the condition of the existing component(s). The conditions generally depend on the age of installation. In addition, the perceived high cost of energy or a positive attitude to reduce energy use may induce the implementation of such measures. Furthermore, the awareness level [7] of such measures influence the adoption.

However, there may be barriers to implement energy efficiency measures. Building owners or housing associations may not adopt such measures due to lack of awareness or lack of adequate and reliable information [9, 10], or the inability to interpret the available information. Furthermore, potential adopters may have difficulties in perceiving the performance and advantages of energy efficiency measures if the gains are not directly visible [11], insignificant, or delayed. Financial constraints such as difficulty to access capital also hinder investments in energy efficiency [12]. Even if owner/organizations have access to capital, still they may not invest in energy efficiency measures due to the perceived risk of such investment. The perceived risk may be due to their inability to understand the performance and benefits of the installation or due to the uncertainty in future energy price. For example, the return on investment for an energy efficiency measure will be less attractive if the energy price falls [12]. In such situation a risk-averse investor may avoid, or postpone or expect higher returns from energy efficiency investments [12]. A potential adopter may be able to collect information about energy efficiency measures from various sources. But, time, money or both is needed to acquire relevant information [13]. Such hidden costs could act as a barrier to invest in energy efficiency. Moreover, organizations might consider other matters for example cleaning and maintenance of the buildings more important than spending resources in energy efficiency.

\section{Methodology}

To investigate the adoption of energy efficiency measures in co-operative apartment buildings we sent a questionnaire to the chairman of about 3000 co-operative housing associations across Sweden. Major building management-decisions in co-operative housing associations are made by an executive board, which is headed by a chairman. The chairmen are in a good position to share information about the implementation of energy efficiency measures in their association's buildings. As the number of such association varies significantly across different regions in Sweden, we sent the questionnaire to about $10-11 \%$ of associations in each of the 21 counties in Sweden to avoid regional bias. The addresses of the associations were collected from Bolagsverket which drew the address randomly. The questionnaires were sent during 
June-October 2010. Some of the associations replied that they could not respond to the questionnaire for various reasons, including their association is very small or their apartments were not currently occupied. Some questionnaires were returned unanswered due to a change in the recipients' addresses. In total, we received approximately 675 completed questionnaires, which corresponded to a response rate of $24 \%$.

\section{Results}

Approximately $50 \%, 19 \%$ and $14 \%$ of the respondents reported that their associations' apartments were heated by district heating, combination with a heat pump and electrical heating, respectively. Approximately 15\% of the respondents thought that their annual heating cost was high, while only $6 \%$ respondents considered their annual electricity cost as high. Still, for $55 \%$ and $38 \%$ of respondents, it was important to reduce heating and electricity use, respectively.

About $80-95 \%$ of the respondents had no intention to retrofit their building envelope components during the next ten years (Table 1). One of the reasons was that they were satisfied with the condition of the existing installations. The majority of the respondents felt that their windows (76\%), attic insulation (59\%), basement insulation (64\%) and insulation of external walls (80\%) were in good condition (Table 2).

Table 1: Plan to improve/change the majority of the building envelope components

\begin{tabular}{llll}
\hline Building envelope components & \multicolumn{4}{c}{ \% of respondents } \\
\cline { 2 - 4 } & No & $\begin{array}{l}\text { Yes, with } \\
\text { in 3 years }\end{array}$ & $\begin{array}{l}\text { Years } \\
\text { ye-10 }\end{array}$ \\
\hline Windows $(\mathrm{N}=578)$ & 79 & 8 & 13 \\
Attic insulation $(\mathrm{N}=555)$ & 84 & 8 & 8 \\
Basement insulation $(\mathrm{N}=534)$ & 94 & 2 & 4 \\
External wall insulation $(\mathrm{N}=548)$ & 94 & 3 & 3 \\
\hline
\end{tabular}

"Do not know" responses were considered as missing value

Table 2: Perceived condition of the building envelope components

\begin{tabular}{lllrr}
\hline Building envelope components & \multicolumn{3}{c}{$\%$ of respondents } \\
\cline { 2 - 5 } & Good & Medium & Bad & Do not know \\
\hline Windows (N=662) & 76 & 19 & 4 & 1 \\
Attic insulation (N=654) & 59 & 25 & 10 & 6 \\
Basement insulation (N=636) & 64 & 19 & 5 & 12 \\
Facade (N=658) & 80 & 16 & 3 & 1 \\
\hline
\end{tabular}

Potential adopters typically compare various energy efficiency measures based on a number of factors. The factors that are given high priority guide the decisions. A ranking of the priority of various factors is presented in Table 3. The results showed that annual energy cost saving and investment cost were the most important factors. Environmental factors were given low priority. $41 \%$ of the respondents reported that their associations consider life cycle cost while making investment intensive measures, while $26 \%$ and $32 \%$ of respondents reported that will not consider life cycle cost and sometime consider such cost, respectively (not shown in the table). 
Table 3: Importance of various factors in respondents' energy efficiency investment decisions

\begin{tabular}{llllc}
\hline & & \multicolumn{3}{c}{ \% of respondents } \\
\cline { 3 - 5 } Factors & $\mathrm{N}$ & Important & Medium & Less important \\
\hline Reduce annual energy cost & 597 & 88 & 10 & 2 \\
Investment cost & 593 & 88 & 9 & 3 \\
Functional reliability & 532 & 70 & 25 & 5 \\
Improve indoor environment & 540 & 60 & 35 & 5 \\
Payback period & 547 & 59 & 30 & 11 \\
Environmental benefit & 523 & 42 & 45 & 13 \\
Improve market value & 525 & 43 & 34 & 23 \\
Technical limitation of buildings (for & 510 & 37 & 41 & 22 \\
example no space to add more insulation) & & & & \\
Reduce greenhouse gas emission & 514 & 32 & 47 & 21 \\
Small/no disturbance to residents & 523 & 33 & 43 & 24 \\
\hline N $=$ Ninnyyy
\end{tabular}

$\mathrm{N}=$ Number of respondents

We compared the respondents' preference of various energy efficiency measures in building envelope to the ten factors mentioned in Table 3. Table 4 shows that significant percentage of respondents did not know about which building envelope components fares better among the various factors. However, those respondents who were aware about performance of building envelope components preferred energy efficient windows followed by improved attic insulation. More respondents were found to be aware or very much aware about energy efficient windows (59\%) than about attic (53\%) or basement $(42 \%)$ or external wall insulation (50\%) improvements (not shown in the table).

Table 4: Preferred building envelope measure against the various factors

\begin{tabular}{|c|c|c|c|c|c|}
\hline & \multicolumn{5}{|c|}{ \% of respondents $(\mathrm{N}=673)$} \\
\hline & $\begin{array}{l}\text { Energy } \\
\text { efficient } \\
\text { window }\end{array}$ & $\begin{array}{l}\text { Attic insulation } \\
\text { improvement }\end{array}$ & $\begin{array}{l}\text { Basement } \\
\text { insulation } \\
\text { improvement }\end{array}$ & $\begin{array}{l}\text { External wall } \\
\text { insulation } \\
\text { improvement }\end{array}$ & $\begin{array}{l}\text { Do } \\
\text { not } \\
\text { know }\end{array}$ \\
\hline $\begin{array}{l}\text { Annual energy cost } \\
\text { reduction }\end{array}$ & 26 & 24 & 7 & 12 & 27 \\
\hline Investment cost & 27 & 21 & 6 & 10 & 25 \\
\hline Functional reliability & 14 & 9 & 3 & 5 & 43 \\
\hline $\begin{array}{l}\text { Improve indoor } \\
\text { environment }\end{array}$ & 19 & 7 & 4 & 7 & 37 \\
\hline Payback period & 9 & 8 & 3 & 6 & 48 \\
\hline Environmental benefit & 11 & 9 & 5 & 6 & 47 \\
\hline $\begin{array}{l}\text { Improve market value of } \\
\text { the property }\end{array}$ & 17 & 7 & 3 & 6 & 44 \\
\hline $\begin{array}{l}\text { Technical limitation of the } \\
\text { buildings }\end{array}$ & 4 & 6 & 4 & 4 & 54 \\
\hline Reduce GHG emission & 7 & 7 & 3 & 5 & 50 \\
\hline $\begin{array}{l}\text { Small/no problem for } \\
\text { residents }\end{array}$ & 8 & 9 & 3 & 5 & 45 \\
\hline
\end{tabular}


Respondents' views on issues that may influence implementation of investment intensive energy efficiency measures (like building envelope components, improvement in ventilation system) are presented in Table 5 . For $54 \%$ of the respondents, lack of expertise of the executive board to assess the benefits of energy efficiency measures was a barrier to such investments. About 35-40\% of respondents thought lack of appropriate and easily available information was a barrier, while economic constraints were reported to be a barrier by $34 \%$ of the respondents. Approximately $77 \%$ of respondents considered the financial position of their association as good and $61 \%$ considered it would be easy to finance renovation of their buildings. Similarly, about $40 \%$ of the respondents reported that their associations were interested to invest in energy efficiency measures if they receive attractive financing (not shown in the table). Respondents' did not think that residents would oppose energy efficiency investment measures. However, in response to another question, a large number of respondents (45\%) believed that if the investment in energy efficiency measure will increase the monthly payment then the residents will resist investments in such measures.

Table 5: Issues regarding investment intensive energy efficiency measures in apartment buildings

\begin{tabular}{|c|c|c|c|}
\hline \multirow[t]{2}{*}{ Statements } & \multicolumn{3}{|c|}{ \% of respondents } \\
\hline & Agree & Neither nor & Disagree \\
\hline $\begin{array}{l}\text { The board does not have own expertise to assess the benefits } \\
\text { of energy efficiency measures }(\mathrm{N}=629)\end{array}$ & 54 & 22 & 24 \\
\hline $\begin{array}{l}\text { Uncertainty about future energy prices makes it difficult to } \\
\text { invest in energy efficiency measures }(\mathrm{N}=608)\end{array}$ & 40 & 31 & 29 \\
\hline $\begin{array}{l}\text { It is difficult to obtain reliable information about costs and } \\
\text { benefits of energy efficiency measures }(\mathrm{N}=611)\end{array}$ & 37 & 33 & 30 \\
\hline $\begin{array}{l}\text { Time and effort required to collect necessary information is } \\
\text { too high }(\mathrm{N}=612)\end{array}$ & 35 & 31 & 34 \\
\hline $\begin{array}{l}\text { Financial constraints makes it difficult to invest in energy } \\
\text { efficiency measures }(\mathrm{N}=611)\end{array}$ & 34 & 29 & 37 \\
\hline $\begin{array}{l}\text { If the association reduce heat energy, district heating } \\
\text { companies will increase energy price, thus making the } \\
\text { effort worthless }(\mathrm{N}=550)\end{array}$ & 26 & 26 & 48 \\
\hline $\begin{array}{l}\text { Changing behaviour like switching off lights is more } \\
\text { beneficial than investments in energy efficiency measures }\end{array}$ & 22 & 40 & 38 \\
\hline $\begin{array}{l}\text { Investments in energy efficiency measures are low priority } \\
\text { compared to other measures }(\mathrm{N}=622)\end{array}$ & 21 & 38 & 41 \\
\hline $\begin{array}{l}\text { Members of association does not support investments in } \\
\text { energy efficiency measures }(\mathrm{N}=609)\end{array}$ & 8 & 34 & 58 \\
\hline $\begin{array}{l}\text { Association has a complex chain of decision making process } \\
\text { which makes it difficult to invest in energy efficiency }\end{array}$ & 7 & 15 & 78 \\
\hline
\end{tabular}

Sweden uses an array of policy instruments to promote energy efficiency in building sector. However, the effectiveness of policy instruments may vary. Majority of respondents considered economic policy instruments, like investment subsidies and tax deductions, as the most effective method to improve energy efficiency (Table 6). More frequent meter reading and energy billing was favoured by less number of respondents. 
Table 6: Chairmen's responses to the question, "Irrespective of how much you know about the following measures - How effective do you think the following measures are to encourage you to implement measures to reduce energy use in your apartment buildings"

\begin{tabular}{|c|c|c|c|}
\hline & \multicolumn{3}{|c|}{$\%$ of respondents } \\
\hline & Effective & $\begin{array}{l}\text { Moderately } \\
\text { effective }\end{array}$ & $\begin{array}{l}\text { Less } \\
\text { effective }\end{array}$ \\
\hline Investment subsidy $(\mathrm{N}=568)$ & 73 & 18 & 9 \\
\hline Tax deduction $(\mathrm{N}=563)$ & 64 & 20 & 16 \\
\hline Individual metering of tap water $(\mathrm{N}=555)$ & 41 & 27 & 32 \\
\hline Individual metering of space heating $(\mathrm{N}=555)$ & 41 & 27 & 32 \\
\hline Building regulations $(\mathrm{N}=546)$ & 34 & 38 & 28 \\
\hline Energy tax $(\mathrm{N}=574)$ & 39 & 32 & 29 \\
\hline Energy declaration $(\mathrm{N}=564)$ & 29 & 31 & 40 \\
\hline Energy labelling (N=531) & 22 & 41 & 37 \\
\hline Carbon dioxide tax $(\mathrm{N}=561)$ & 27 & 33 & 40 \\
\hline More frequent reading of energy $(\mathrm{N}=550)$ & 28 & 29 & 43 \\
\hline Electricity certificate $(\mathrm{N}=551)$ & 20 & 38 & 42 \\
\hline Voluntary program $(\mathrm{N}=528)$ & 14 & 40 & 46 \\
\hline More frequent billing of energy $(\mathrm{N}=549)$ & 22 & 26 & 52 \\
\hline
\end{tabular}

$\mathrm{N}=$ Number of respondents

\section{Discussion and Conclusions}

Approximately 55\% of the chairmen of co-operative housing associations' have a positive attitude to reduce heat use. The lower concern towards electricity use by the respondents could be because the household electricity bill is usually metered separately and the collective burden of electricity cost is less. However, majority of co-operative housing association did not intend to replace/change majority of their building envelope components during the next ten years. One of the reasons is that the associations were satisfied with the condition of existing building envelop components. In this situation, it is important to increase the awareness of energy efficient alternatives. A large percentage of respondents were not aware about the various energy efficient possibilities in building envelope. Moreover, about $35-40 \%$ of respondents thought lack of appropriate and easily available information was a barrier to implement energy efficiency investment measures. Information stressing the cost benefits of the energy efficient alternatives should be effectively communicated. The source of information is also very important in the adoption of investment measures. Hence, it is necessary to use the sources such associations consider important in adoption of energy efficiency measures.

As annual energy cost reduction is a very important guiding factor in associations' adoption of energy efficiency measures, information campaigns announcing the cost advantages of energy efficiency measures may be helpful in adoption decisions. However, majority (54\%) of respondents reported that they did not have the expertise to assess the benefits of energy efficiency measures, while $34 \%$ of respondents reported financial constraints as the barrier. Innovative energy efficiency renovation package which include consulting, financing, contract work and follow up may be able to tap this segment. 
Since respondents gave higher priority to reduce the annual cost of energy than to environmental benefits, increasing energy prices using economic instruments to internalise the environmental costs could encourage people to implement energy efficiency measures. In Sweden, external cost of energy use is internalized through taxes on emission of $\mathrm{CO}_{2}$, sulphur and $\mathrm{NO}_{\mathrm{x}}$. However the price elasticity of energy demand in Sweden is low [14], and in such situations imposition of taxes to reduce energy use may be less effective [15].

Respondents gave high priority to investment cost in their energy efficiency decisions. Respondents also favour economic policy instruments compared to other policy instruments as the most effective method to improve energy efficiency. Subsidies may encourage the adoption of investment intensive energy efficiency measures by reducing the investment cost. The cost effectiveness of the subsidies could be improved by restricting its beneficiaries, for example subsidies may be granted based on the age of the components/buildings.

More respondents were unsatisfied with their attic insulation compared to other building envelope components. However, the respondents were more likely to replace windows than attic insulation. This could be because windows have a higher degree of observability as compared to attic insulation. If we encounter a problem frequently, we give priority to that problem more so than to others that are less observable [16]. Also more respondents had a favourable attitude towards energy efficient windows compared to other building envelope measures on various factors that influence the adoption decision.

A large percentage of respondents were unaware about various aspects of different energy efficient building envelope measures. The situation calls for measures to improve awareness about such measures among co-operative housing associations. As many respondents were not satisfied by the attic insulation of their buildings, it may be relatively easier to influence them to implement energy efficiency improvements in the attic insulation.

\section{Acknowledgments}

The authors gratefully acknowledge the financial support from the Swedish Energy Agency and from the European Union.

\section{References}

[1] STEM. Energy in Sweden 2009, Swedish Energy Agency, Eskilstuna, Sweden.

[2] A, Werner, External Water Condensation and Angular Solar Absorptance: Theoretical Analysis and Practical Experience of Modern Windows. PhD Thesis. Uppsala University, Sweden, 2007, ISSN 1651-6214.

[3] D, Avasoo, The European window energy labelling challenge. In: Proceedings of the European council for an energy efficient economy (ECEEE) summer study, Côte d'Azur, Paris, France; 4 -9 June, 2007.

[4] SCB, Yearbook of Housing and Building Statistics 2009 [Bostads- och byggnadsstatistisk årsbok 2009], Statistics Sweden, Örebro, Sweden, ISSN 1654-0921.

[5] B. Turner, Housing cooperatives in Sweden: The effects of financial deregulation, Journal of Real Estate Finance and Economics 15, 1997, pp 193- 217.

[6] E. Hassinger, Stages in the adoption process. Rural Sociology 24, 1959, pp 52-3.

[7] E.M. Rogers, Diffusion of Innovations, The Free Press, New York, 2003. 
[8] D.I. Hawkins, D.L. Mothersbaugh, R.J Best, Consumer Behavior: Building Marketing Strategy. McGraw Hill/Irwin, New York, 2007.

[9] S. Birner, E. Martinot, Promoting energy-efficient products: GEF experience and lessons for market transformation in developing countries, Energy Policy 33, 2005, pp 17651779 .

[10] S. Owens, L. Driffill, How to change attitudes and behaviours in the context of energy, Energy Policy 36, 2008, pp 4412-4418.

[11] M. Levine, D. Ürge-Vorsatz, K. Blok, L. Geng, D. Harvey, S. Lang, G. Levermore, M.A. Mehlwana, S. Mirasgedis, A. Novikova, J. Rilling, H. Yoshino, Residential and commercial buildings. In Climate Change 2007: Mitigation. Contribution of Working Group III to the $4^{\text {th }}$ Assessment Report of the IPCC, Cambridge University Press. NY, 2007.

[12] J. Schleich, E. Gruber, Beyond case studies: Barriers to energy efficiency in commerce and service sector, Energy Economics 30, 2008, pp 449-464.

[13] W.H. Golove, J.H. Eto, Market barriers to energy efficiency: A critical reappraisal of the rationale for public policies to promote energy efficiency. Lawrence Berkeley National Laboratory, University of California, Berkeley, California, 1996.

[14] J. Nässén, F. Sprei, J. Holmberg, Stagnating energy efficiency in the Swedish building sector -Economic and organisational explanations, Energy Policy 36, 2008, pp 38143822.

[15] D. Ürge-Vorsatz, S. Koeppel, S. Mirasgedis, Appraisal of policy instruments for reducing buildings' CO2 emissions, Building Research \& Information 35, 2007, pp 458 -477 .

[16] E. Milbourne. Perception and individual decision making; 2001. <http:// home.ubalt.edu/ntsbmilb/ob/ob3/tsld001.htm> [accessed 02.12.10]. 